\title{
Quality Perception Evaluation: A Case Study of a Private Bank Branch in Campina Grande, PB
}

\author{
Allan Carlos Alves ${ }^{1}$, Ângela Maria Cavalcanti Ramalho' ${ }^{1}$, Sandra Sereide Ferreira da Silva ${ }^{2}$, \\ Cicero de Sousa Lacerda², Juaceli Araújo Lima², Fabio Adriano Pereira da Silva ${ }^{1}$ \\ ${ }^{1}$ State University of Paraíba-UEPB, Campina Grande, Brazil \\ ${ }^{2}$ Federal University of Campina Grande-UFCG, Campina Grande, Brazil \\ Email: allan.adm@gmail.com, angelamcramalho@gmail.com, sandrasereide@yahoo.com.br, \\ lacerdatur@gmail.com, juacelima@gmail.com, fabioadriano2@gmail.com
}

Received 31 March 2015; accepted 15 June 2015; published 18 June 2015

Copyright (C) 2015 by authors and Scientific Research Publishing Inc.

This work is licensed under the Creative Commons Attribution International License (CC BY).

http://creativecommons.org/licenses/by/4.0/

(c) (i) Open Access

\begin{abstract}
Marketing can be understood as the instrument used by companies to determine the needs of its customers and to create mechanisms in order to supply such needs and bring the company better chances of success. The financial sector in Brazil often involves great challenges; thus as to survive and grow in marketing it is necessary to implement some actions that enable greater proximity between companies and customers; to understand their needs and to be more flexible in order to offer more quality, individually. Currently, there is no significant differential used by the companies on their products and services, and therefore, it is necessary to create marketing strategies so as to achieve and maintain market share. Thus, the purpose of this paper is to evaluate the perception of quality in the services provided by a bank, located in Campina Grande, Paraíba, Brazil. Regarding the methodological aspects, this study is characterized as exploratory and descriptive, being a case study, with a quantitative analysis approach. The findings revealed that the agency still falls short in many criteria that concern its customers. Consequently, it is necessary that the company improves its employees' qualification, starts to listen and respond to customers' suggestions, and also has some flexibility in its services. Therefore, the agency should review the points that should be improved in order to prevent their customers to seek for services provided by other agencies that offer quality services.
\end{abstract}

\section{Keywords}

Marketing, Services, Quality Services 


\section{Introduction}

Human beings have always sought ways to meet their needs, as they have always worked with the intention to provide everything that was necessary for their survival. In the nineteenth century, the thought was totally focused on financial and production issues, and marketing was considered an isolated activity from the other business functions.

It was just in the early 1920s that companies have adopted means to offer products that interested the market. Now, companies try to meet the specific needs of its customers, through the manufacture of products or services. With this, their activities have been planned in accordance with the customer needs, making it necessary to adopt market research and sales promotion so as to achieve customers' wishes more accurately [1].

The most modern marketing concepts emerged in the post-war period, during the 1950s when it was used warfare techniques in the marketing field. Advertisements began to make use of psychological appeals and it emerged new methods of personal selling and advertising in order to attract more customers. Marketing began to be used as a powerful differential between companies that seeks the organizational success through customer satisfaction [2].

Thus, marketing can be understood as the instrument used by companies to determine the needs of its customers and to create mechanisms that allow supplying these needs, and as a result, bring the company great chances of success.

It is noteworthy that the financial sector in Brazil often involves great challenges, and in order to survive and grow in marketing it is necessary to implement some actions that allow greater proximity between companies and customers; to understand their needs and to be more flexible so as to offer more quality, individually. Currently, there is no significant differential used in the institutions on their products and services, and thus, it is necessary to create marketing strategies in order to achieve and maintain market share.

Given the context, the following question arises: Are banks' customers satisfied with the services they are provided?

In order to answer this question, some goals were outlined in this paper. The overall objective was to evaluate the perception of quality in the services of a private bank, located in Campina Grande, Paraíba. The specific objectives were: 1) to outline a customer profile; 2 ) to ascertain whether the services are meeting the needs of customers; and 3) to propose solutions to possible problems.

With regard to the methodological aspects, this study is characterized as exploratory and descriptive, being a case study, with a quantitative analysis approach. It is expected that this study could contribute to the financial institutions, and that they therefore, could better meet the needs of its customers, and provide higher quality services in order to stand out in the market.

\section{Theoretical Framework}

\subsection{Definitions and Concepts of Marketing}

Management's activities are heavily influenced by marketing, which among many other functions is responsible for placing the product or service in the market and transforming it into a financial success to the company. This financial success can only be achieved in a sustainable manner through the satisfaction and maintenance of the customer needs, through marketing.

Thus, marketing is defined as [3]:

[...] Analysis, planning, implementation and control of carefully formulated programs in order to cause voluntary exchanges of values with target markets and then, achieve institutional goals. Marketing involves programing the institution's offers in order to meet the needs and wants of target markets, using price, effective communication and distribution to inform, motivate and serve these market

In agreement with it, marketing is also defined as "the word used to express the action directed to the market. Therefore, the company engaged with marketing has the market as the reason and the focus of their actions". Marketing can be used as a management tool, when they claim that it is an orientation that aims to provide the customer satisfaction and welfare as a way of meeting the objectives and the organization's responsibilities [1] [4].

Moreover, marketing can be defined as an organizational function and a set of processes. These processes involve the creation, communication and delivery of value to customers, and also provide a relationship with them, 
bringing benefits to the organization and its target audience [2].

\subsection{Services}

The Western world is experiencing a "society of services" or a "service economy", as the economy is characterized by more than half of the country's wealth to be produced in the service sector [5].

It is noticeable that in the recent decades, services have become an important part of the global economy, accounting for a significant portion of the gross domestic product of several countries, mainly the industrialized ones.

Define what is a service is considered a fairly complex task, since this word can have several meanings ranging from personal servicel to service as a product [5].

Service consists of "activities, benefits or satisfactions that are offered for sale or are provided in connection with the sale of goods" [6].

A service is considered a series of activities arising through numerous interactions between clients, structures, human resources, assets and systems provider, using this set of interactions to meet the need of the customer [7].

Service definition can be understand as follows: "Service is any act or performance that one party can offer to another that is essentially intangible and that does not result in the ownership of anything". And services have the following characteristics [8] [9]:

1) Intangibility: When it comes to services we can describe them as intangible, since they cannot be seen, tasted, felt, heard or smelled before they are bought. Buyers seek to know about its quality based on the location, the staff, the equipment, the communication material, the symbol and the perceived price.

2) Inseparability: The services are produced and consumed simultaneously, except for physical goods that are manufactured, stored, distributed through retailers, and later consumed. The person providing the service is already part of it.

3) Variability: Services basically depend on either who perform them and the place where they are provided. As a result, they are highly variable. Often, buyers of services are aware of this variability, and will always talk with others before choosing their provider. Companies may offer services with quality control, for instance, investing in staff training, standardizing the service delivery process across the organization and monitoring customer satisfaction through suggestion, claims and comparisons systems, allowing them to detect the weaknesses of their service and thus, making it possible to correct.

4) Perishability: It is a fact that services cannot be stored, but the perishability of them is not a problem, when the demand is stable.

\subsection{Satisfaction}

The first critical task of marketing is to identify the needs of customers. In order to do this, it is necessary to find out what are the market wishes so that it would be possible to satisfy them through a consistent strategy.

Satisfaction is a key element for the company achieve the loyalty of its customers. Therefore, it should seek for satisfaction as a way to make the customers its trading partners.

Satisfaction "is the state of progress achieved when the performance of the product equals the customer expectation or exceeds it" and "the result of a person's experiences when a performance or a result met their expectations". Moreover, "satisfaction is a function of relative levels of expectation and perceived performance" [1] [3].

Satisfaction can be seen as the "feeling of pleasure or disappointment resulting from comparing the performance (or result) perceived from a product and the buyer's expectations" [2].

It is noticeable the concern to offer a product or service that manages customers' expectations as to convince them to purchase. Therefore, it is expected that this product have a good performing, that means, that it allows to meet those expectations and engender satisfaction [2].

Determining the level of customers' satisfaction and understanding their relation to the financial results of the organization, are becoming important components for managing the process of improving the quality of services and products offered by organizations [10].

It is important to measure regularly the levels of customers' satisfaction, so that they remain loyal to the organization. This measurement can be done through several methods. One of them is the periodic survey, which evaluates customers' satisfaction regarding their purchase and their future purchase intentions. Another method 
of evaluation is the customer churn rate, which seeks those customers who no longer buy from that company and try to discover the reason of it. The quality of the product or service is the key used to the clients' satisfaction and value. Therefore, customers' satisfaction is related to product performance as a service used to meet their necessity [2].

By identifying customers' needs, it is possible to notice if their expectations for the product are positive or negative. If their expectations are positive, it is probable that they will return to the company and give good references to it. On the other hand, if they are negative, it is possible that they do not return to the company [2].

It is important to highlight that the organization has the responsibility to serve the diverse public, and that the satisfaction increase of one of the groups involved may decrease the satisfaction of another one. In this case, the institution must seek for a balance, providing acceptable levels of satisfaction within the limits of resources presented [2].

\section{Methodology}

The sampling frame from data collection covers 1200 respondents, between 18 and 56 years old, who were selected from a random interception in the city of Campina Grande-PB, using age-stratified sampling. The fieldwork took place in June 2014, resulting in 900 valid questionnaires. All variables in the questionnaire presented the Likert scale of 5 points $(1=$ low and 5 = high). Data were tabulated using Excel 2000 with basic statistics.

\section{Data Analysis}

Initially, it was made a socio-demographic profile survey of the agency's clients involved in the research, in order to assess the demographic characteristics of all of them, and present a percentage relative to the total sample, as follows:

Regarding customer age, as we can see from Table 1, 49\% were aged from 26 to 35 years old; 25\% from 45 to 55 years old; $11 \%$ from 36 to 45 years old; $9 \%$ were older than 56 years old, and $6 \%$ were from 18 to 25 years old. The data showed that most of the customers are in the age group considered as young, that are adults and median age people, which might mean that younger customers are the ones who hire the most the banking services of that agency.

From the customers surveyed, $54 \%$ were represented by men and $46 \%$ of the total sample was represented by women (Table 2).

Regarding marital status, $56 \%$ of respondents were single, $30 \%$ said they were already married, and $14 \%$ said they had other marital status (Table 3).

Finally, regarding the client's time of agency $36 \%$ of the respondents were customers for two years, $29 \%$ for a

\section{Table 1. Age.}

\begin{tabular}{llc}
\hline & & Percentage \\
\hline From 18 to 25 years old & $06 \%$ \\
& From 26 to 35 years old & $49 \%$ \\
& From 36 to 45 years old & $11 \%$ \\
& From 46 to 55 years old & $25 \%$ \\
& Older than 56 years old & $09 \%$ \\
\hline
\end{tabular}

Source: Field research, 2014.

Table 2. Gender.

\begin{tabular}{ccc}
\hline & Percentage \\
\hline Male & $54 \%$ & $4 \%$ \\
Female & $46 \%$ \\
\hline
\end{tabular}

Source: Field research, 2014. 
year, $22 \%$ for three years, and $13 \%$ of the representatives are clients of the agency for less than a year. Thus, it appears that most people surveyed are a client of the company for more than one year. It is noteworthy that the company has existed for almost four years (Table 4).

\subsection{Evaluation of Quality Criteria in the Services}

Six criteria were analysed in accordance with the criteria established in the studies of Las Casas, Grönroos and Gianese and Correia, as presented before, in the theoretical framework and in the methodology. Thereby, the following analysis presents each of the six criteria, specifying each of its variables [5] [11] [12].

\subsubsection{Employee's Competence}

The first variable was related to the staff's knowledge required to provide the services, the results revealed that: $36 \%$ of the customers were partially satisfied, $28 \%$ dissatisfied, $20 \%$ satisfied, $11 \%$ very satisfied and $5 \%$ very dissatisfied. Thus, it is noticeable that there is a mixture of satisfaction and dissatisfaction among customers. Thereby, for these results to be homogeneous for satisfaction, the agency should provide periodic training to its employees, qualifying them so that they could serve customers and their needs satisfactorily (Table 5).

This variable evaluated the contacts made between employee and customer about information of benefits. The findings revealed that $39 \%$ of the respondents were dissatisfied, $22 \%$ were partially satisfied, $16 \%$ were satisfied, $12 \%$ were very dissatisfied and $11 \%$ were very satisfied. By seeing these results, it is noticeable that many of the customers are not satisfied with the contact forms for providing information about the benefits which they are entitled. Therefore, customers can feel harmed as they might not know about their entitlement or, sometimes, the information is not conveyed properly and they end up misunderstanding it (Table 6).

The last variable in this criterion is related to employees' commitment to solve problems, and it revealed that:

Table 3. Marital status.

\begin{tabular}{ccc}
\hline & Percentage \\
\hline Married & $30 \%$ & $56 \%$ \\
Single & $14 \%$ \\
\hline
\end{tabular}

Source: Field research, 2014.

Table 4. Client's time of agency.

\begin{tabular}{cc}
\hline & Percentage \\
\hline Few months & $13 \%$ \\
1 year & $29 \%$ \\
From 1 to 2 years & $36 \%$ \\
From 2 to 3 years & $22 \%$ \\
\hline
\end{tabular}

Source: Field research, 2014.

Table 5. Staff's knowledge needed to provide the services.

\begin{tabular}{ccc}
\hline & Percentage \\
\hline Very dissatisfied & $5 \%$ \\
Dissatisfied & $28 \%$ \\
Partially satisfied & $36 \%$ \\
Satisfied & $20 \%$ \\
Very satisfied & $11 \%$ \\
\hline
\end{tabular}

Source: Field research, 2014. 
$41 \%$ of the customers were dissatisfied, $25 \%$ were partially satisfied, $13 \%$ were satisfied, $11 \%$ were very satisfied and $10 \%$ were very dissatisfied. These results show that most of the agency clients are dissatisfied with the employees when they expect for some commitment to solving problems that do not occur. Consequently, employees should show greater promptness and try in various ways to solve any problem which may harm the services used by customers (Table 7).

This criterion revealed a high rate of dissatisfaction among customers, which reveals that the company lacks of staff competence to perform the services with quality, so that customers continue to use its services, more specifically, the agency services.

\subsubsection{Time Spent on Service}

When customers were asked if their requests were completed in the estimated time for service, $46 \%$ of them were dissatisfied with it, $26 \%$ were partially satisfied, $12 \%$ were satisfied, $11 \%$ were very satisfied, $8 \%$ were very dissatisfied. It is clear that customer requirements are not being met by the deadline, which creates dissatisfaction. Therefore, it is the agency obligation to improve the efficiency of service and to meet deadlines, considering that sometimes customers might have limited time and could not stay too long in the agency to get the services. That could be a reason for the clients to end up using another agency services (Table 8).

Another variable of this criterion was "Do Living Line, BCN Net Internet Banking and Self-Service Baking System, facilitate your operations?” The result was: $44 \%$ said they were dissatisfied, $27 \%$ were partially satisfied, $10 \%$ were satisfied, $10 \%$ were very satisfied and $9 \%$ were very dissatisfied. The agency is not offering

Table 6. Contact between staff and clients regarding information benefits.

\begin{tabular}{ccc}
\hline & Percentage \\
\hline Very dissatisfied & $12 \%$ \\
Dissatisfied & $39 \%$ \\
Partially satisfied & $22 \%$ \\
Satisfied & $16 \%$ \\
Very satisfied & $11 \%$ \\
\hline
\end{tabular}

Source: Field research, 2014.

Table 7. Staff commitment to solve problems.

\begin{tabular}{ccc}
\hline & & Percentage \\
\hline Very dissatisfied & $10 \%$ \\
Dissatisfied & $41 \%$ \\
Partially satisfied & $25 \%$ \\
Satisfied & $11 \%$ \\
Very satisfied & $13 \%$ \\
\hline
\end{tabular}

Source: Field research, 2014.

Table 8. Requests completed in the estimated time.

\begin{tabular}{cc}
\hline & Percentage \\
\hline Very dissatisfied & $8 \%$ \\
Dissatisfied & $46 \%$ \\
Partially satisfied & $26 \%$ \\
Satisfied & $12 \%$ \\
Very satisfied & $11 \%$ \\
\hline
\end{tabular}

Source: Field research, 2014. 
quality services with regard to the use of alternative means of assistance, which can cause problems with customers, since many of them do not have time to be in the agency to be served at opening hours and prefer to use other means to perform their services. It is for the agency to realize how to facilitate the customers' service (Table 9).

Regarding the speed in which the services are performed, the data revealed that: $57 \%$ were dissatisfied, $17 \%$ were very dissatisfied, $17 \%$ were partially satisfied, $4 \%$ were satisfied and $5 \%$ were very satisfied. It is noticeable that most of the surveyed customers are dissatisfied with the speed at which services are provided. Then, the agency must try to speed up the process, by either qualifying employees or adapting their equipment so that it does not take so much time to provide the customer services (Table 10).

Regarding the speed criterion of service the dissatisfaction of customers was again in evidence, which means that the company is falling short as the agility in their services and therefore, must make changes so that it could retain its customers and keep them satisfied so that they would continue performing their services at the agency.

\subsubsection{Service/Atmosphere Addressed to the Client}

When it was asked if the employees demonstrate cordiality in attendance, the results showed that $32 \%$ were satisfied, $31 \%$ were very satisfied, $28 \%$ were partially satisfied, were dissatisfied $6 \%$, and $3 \%$ were very dissatisfied. As it is possible to notice, in this variable, customers expressed a high percentage of satisfaction regarding the way they are treated by agency employees (Table 11).

The second criterion was related to if the employees showed interest in solving problems spontaneously and

Table 9. Facilities on the operation.

\begin{tabular}{ccc}
\hline & Percentage \\
\hline Very dissatisfied & $9 \%$ \\
Dissatisfied & $44 \%$ \\
Partially satisfied & $27 \%$ \\
Satisfied & $10 \%$ \\
Very satisfied & $10 \%$ \\
\hline
\end{tabular}

Source: Field research, 2014.

Table 10. Service speed.

\begin{tabular}{ccc}
\hline & Percentage \\
\hline Very dissatisfied & $17 \%$ \\
Dissatisfied & $57 \%$ \\
Partially satisfied & $17 \%$ \\
Satisfied & $4 \%$ \\
Very satisfied & $5 \%$ \\
\hline
\end{tabular}

Source: Field research, 2014.

Table 11. Staff's cordiality in service.

\begin{tabular}{ccc}
\hline & Percentage \\
\hline Very dissatisfied & $3 \%$ \\
Dissatisfied & $6 \%$ \\
Partially satisfied & $28 \%$ \\
Satisfied & $32 \%$ \\
Very satisfied & $31 \%$ \\
\hline
\end{tabular}

Source: Field research, 2014. 
amicably and it revealed that: $39 \%$ of the customers were dissatisfied, $22 \%$ were partially satisfied, $16 \%$ were satisfied, $12 \%$ were very dissatisfied, and $11 \%$ were very satisfied. Consequently, most of the customers are dissatisfied with the way employees behave when they should solve some problems. It is therefore, up to the agency to better instruct their employees so that they can solve the customer problems in a cordial and friendly way, without any disturbance (Table 12).

Finally, it was asked whether the customer suggestions are received with proper care, and 57\% reported being dissatisfied, $17 \%$ being very dissatisfied, $17 \%$ being partially satisfied, $5 \%$ being very satisfied, and $4 \%$ being satisfied. Thus, most of the customers are unhappy when it comes to giving suggestions as they are not attended. The agency does not seem to "listen" and accept suggestions in order to provide the changes needed (Table 13).

This criterion showed that employees treat customers cordially, but when it comes to be friendly at the time problems arise, they are not friendly anymore and also do not give the proper importance to customers' opinion. The agency should focus more on customer suggestions, at least, listening to them and showing respect. Likewise, the employees must show cordiality even when any problems arise, as it is not the client's fault.

\subsubsection{Flexibility}

The first variable in this criterion was "Did the baking automation bring benefits to the services provided?", the results were: $30 \%$ of the respondents were satisfied, $29 \%$ were very satisfied, $28 \%$ were partially satisfied, were $8 \%$ dissatisfied, and $5 \%$ were very dissatisfied. In this aspect, it is possible to notice that most of the customers are satisfied, that is, the banking automation facilitated the provision of services as it is more flexible since it is not needed a direct contact between client and staff (Table 14).

Table 12. Employees’ interest in solving problems amicably and spontaneously.

\begin{tabular}{ccc}
\hline & Percentage \\
\hline Very dissatisfied & $12 \%$ \\
Dissatisfied & $39 \%$ \\
Partially satisfied & $22 \%$ \\
Satisfied & $16 \%$ \\
Very satisfied & $11 \%$ \\
\hline
\end{tabular}

Source: Field research, 2014.

Table 13. Receiving and attending clients’ suggestions.

\begin{tabular}{ccc}
\hline & & Percentage \\
\hline Very dissatisfied & $17 \%$ \\
Dissatisfied & $57 \%$ \\
Partially satisfied & $17 \%$ \\
Satisfied & $4 \%$ \\
Very satisfied & $5 \%$ \\
\hline
\end{tabular}

Source: Field research, 2014.

Table 14. Banking automation as a way of providing benefits to service.

\begin{tabular}{ccc}
\hline & Percentage \\
\hline Very dissatisfied & $5 \%$ \\
Dissatisfied & $8 \%$ \\
Partially satisfied & $28 \%$ \\
Satisfied & $30 \%$ \\
Very satisfied & $29 \%$ \\
\hline
\end{tabular}

Source: Field research, 2014. 
When it was questioned if the services were adapted to the client's needs the data revealed that $31 \%$ of customers were dissatisfied, $31 \%$ were partially satisfied, $27 \%$ were very unhappy, $6 \%$ were satisfied, and $5 \%$ were very satisfied. Thus, most of the customers are dissatisfied, since the agency does not seem to make adaptations in order to meet the needs of its customers. Therefore, the company should try to start making adaptations so that the clients do not feel harmed (Table 15).

If the service was flexible to complaints was the last question of this criterion, and showed the following results: $34 \%$ of the customers were dissatisfied, $29 \%$ were partially satisfied, $24 \%$ were very unhappy, $7 \%$ were satisfied, and $6 \%$ were very satisfied. One more time, customers were dissatisfied because the agency does not seem to take their opinion in consideration, especially their complaints. The agency falls short in its service and as a result the customers look for other banks and agencies (Table 16).

In this criterion, we can see that customers are dissatisfied because the agency does not seem to show flexibility to the customers' needs as it should.

\subsubsection{Services Access}

Regarding the access to the banking self-service, the first question of the criterion was: do the cash machines are well distributed and able to be used comfortably? The results showed: $35 \%$ of satisfied customers $21 \%$ of partially satisfied customers, $19 \%$ of dissatisfied customers, $15 \%$ of very satisfied customers, and $10 \%$ of very dissatisfied customers. Thus, there was a mix between satisfaction and dissatisfaction, that is, some customers were satisfied with the banking self-service, and others were not (Table 17).

Table 15. Adaptations to meet clients' needs.

\begin{tabular}{ccc}
\hline & Percentage \\
\hline Very dissatisfied & $27 \%$ \\
Dissatisfied & $31 \%$ \\
Partially satisfied & $31 \%$ \\
Satisfied & $6 \%$ \\
Very satisfied & $5 \%$ \\
\hline
\end{tabular}

Source: Field research, 2014.

Table 16. Flexibility to complaints.

\begin{tabular}{ccc}
\hline & Percentage \\
\hline Very dissatisfied & $24 \%$ \\
Dissatisfied & $34 \%$ \\
Partially satisfied & $24 \%$ \\
Satisfied & $7 \%$ \\
Very satisfied & $6 \%$ \\
\hline
\end{tabular}

Source: Field research, 2014.

Table 17. Access to the banking self-service, cash machine distribution and comfortability of use.

\begin{tabular}{ccc}
\hline & Percentage \\
\hline Very dissatisfied & $10 \%$ \\
Dissatisfied & $19 \%$ \\
Partially satisfied & $21 \%$ \\
Satisfied & $35 \%$ \\
Very satisfied & $15 \%$ \\
\hline
\end{tabular}

Source: Field research, 2014. 
Another variable was related to how to operate the cash machines in the baking self-service area as well as other automated instruments used by the bank, checking if they were clear, precise and easy to manage. $39 \%$ of the customers were partially satisfied with it, $18 \%$ were dissatisfied, $16 \%$ were very satisfied, $15 \%$ were satisfied and $12 \%$ were very dissatisfied. There was, again, a mixed response regarding the satisfaction and dissatisfaction with the automated services, which means that not everyone is used to handling such machines, and consequently, the agency should make someone available to help customers whenever they have difficulties in using them (Table 18).

By questioning about the facility of access to management: $44 \%$ of the customers were partially satisfied, $29 \%$ were satisfied, $19 \%$ were very satisfied, $5 \%$ were dissatisfied, $3 \%$ were very dissatisfied. It is noticeable that most of the customers were satisfied with it, which shows that when you need to consult the management there is no difficulty, despite as mentioned before, customers allege that they do not take the customer's complaints (Table 19).

This criterion showed in the first questions a mix between satisfaction and dissatisfaction, consequently the bank should verify the possible failures and try to improve them. Regarding access to management, customers were satisfied, which shows that it is important to continue cultivating this relationship with customers, and to listen to their criticisms related to the agency.

\subsubsection{Perception on Tangible Aspects}

Regarding the location and the access to the agency, customers showed that: $46 \%$ were satisfied with its location, $28 \%$ were partially satisfied, $24 \%$ were very satisfied, $2 \%$ were dissatisfied and none of them said that were very dissatisfied. Thus, it is clear that customers were satisfied with the agency being located downtown, which facilitates the access to its service (Table 20).

\section{Table 18. Operation of automated instruments.}

\begin{tabular}{ccc}
\hline & Percentage \\
\hline Very dissatisfied & $12 \%$ \\
Dissatisfied & $18 \%$ \\
Partially satisfied & $39 \%$ \\
Satisfied & $15 \%$ \\
Very satisfied & $16 \%$ \\
\hline
\end{tabular}

Source: Field research, 2014.

Table 19. Access to management.

\begin{tabular}{ccc}
\hline & \multicolumn{2}{c}{ Percentage } \\
\hline Very dissatisfied & $3 \%$ & $5 \%$ \\
Dissatisfied & $44 \%$ & $29 \%$ \\
Partially satisfied & Satisfied & $19 \%$ \\
\hline
\end{tabular}

Source: Field research, 2014.

Table 20. Agency location.

\begin{tabular}{ccc}
\hline & Percentage \\
\hline Very dissatisfied & $0 \%$ & $2 \%$ \\
Dissatisfied & $28 \%$ & $46 \%$ \\
Partially satisfied & Satisfied & $24 \%$ \\
\hline
\end{tabular}

Source: Field research, 2014. 
In the sequence, customers were asked about the "agency condition (cleaning, painting, etc.)" and the data revealed that: $46 \%$ of the customers were satisfied with it, $28 \%$ were partially satisfied, $24 \%$ were very satisfied, $2 \%$ were dissatisfied and none of them said that were very dissatisfied, showing that, regarding the physical environment, the customers were satisfied and the agency does not lack at this point (Table 21).

As for the parking area, regarding its capacity and access, the data showed that: $34 \%$ of the customers were dissatisfied with it, $28 \%$ were very dissatisfied, $17 \%$ were partially satisfied, $12 \%$ were satisfied, and $4 \%$ were very satisfied. At this criterion, customers were dissatisfied because the agency lacks a larger parking lot in order to meet the customers' needs (Table 22).

Regarding the tangible aspects, the agency is located in a great place and has a salubrious environment for customers, though with regard to parking, it does not have enough space to meet all of them.

\section{Final Considerations}

The information quality in serving the public is essential in any activity or sector to customer satisfaction. Therefore, it is important that organizations are always willing to be evaluated, especially in the area of services, since it is a growing industry today.

The present study was structured based on its overall objective: to evaluate the perception of quality in services of a private bank, located in Campina Grande, Paraíba.

The data showed that the agency has no service quality in some quality criteria that were analysed, as customers showed a high indicator of dissatisfaction, especially regarding the staff's competence, the speed in performing the services and the flexibility to customers' needs. On the order hand, it showed satisfaction regarding the location and the access to management.

The agency should change their strategies and listen to its customer's suggestions and complaints in order to improve its service and better attend its customers. In addition, it should also provide training to its employees so that they can serve customers in a friendly way even when dealing with problems.

As a result, the agency should review the points that it need to improve so that its customers do not seek for services provided by other agencies that offers quality services.

It is worth noting that this study had some limitations, such as the resistance of some clients to participate in it.

Table 21. Agency condition.

\begin{tabular}{cc}
\hline & Percentage \\
\hline Very dissatisfied & $0 \%$ \\
Dissatisfied & $2 \%$ \\
Partially satisfied & $28 \%$ \\
Satisfied & $46 \%$ \\
Very satisfied & $24 \%$ \\
\hline
\end{tabular}

Source: Field research, 2014.

Table 22. Parking lot.

\begin{tabular}{cc}
\hline & Percentage \\
\hline Very dissatisfied & $28 \%$ \\
Dissatisfied & $34 \%$ \\
Partially satisfied & $17 \%$ \\
Satisfied & $12 \%$ \\
Very satisfied & $4 \%$ \\
\hline
\end{tabular}

Source: Field research, 2014. 
And as a suggestion for future work, another study could investigate other quality criteria.

\section{References}

[1] Dias, S.R. (2006) Gestão de marketing. Saraiva, São Paulo.

[2] Kotler, P. and Keller, K.L. (2007) Administração de Marketing. Pearson, São Paulo.

[3] Kotler, P. and Fox, K.F.A. (1994) Tradução de Ailton Bonfim Brandao marketing estratégico para instituições educacionais. Atlas, Rio de Janeiro.

[4] Matos, L.R.A. (2004) A relevância do merketing nas instituições particulares de ensino superior da cidade do Rio de Janeiro: Uma análise critica dos modelos aplicados às IES. https://pt.scribd.com/doc/38702990/A-RELEVANCIA-DO-MARKETING-NAS-INSTITUICOES

[5] Grönroos, C. (2009) Marketing: Gerenciamento e serviços. Trad. de Cristina Bazán. Rio de Janeiro, Campus.

[6] American Marketing Association (1960) A Glossary of Marketing Terms. Chicago.

[7] Téboul, J. (1999) A era dos serviços: Uma nova abordagem ao gerenciamento. Qualitymark, Rio de Janeiro.

[8] Kotler, P. (1998) Marketing sem segredos. Bookman, Porto Alegre.

[9] Lobo, J.R.M. and de Abreu, J.A.P. (2007) Atributos de Valor Determinantes Para a Escolha de Uma IES Na Perspectiva dos Clientes Potenciais de Um Curso de Especialização Em Finanças. http://www.latec.uff.br/bt/V2008/numero1/PDF/BT026_2007.pdf

[10] Figurelli, J.C.R. (2001) Qualidade em instituições de ensino superior: Um estudo de caso - avaliando as percepções dos públicos envolvidos. http://biblioteca.universia.net/autor/Figurelli,\%20Jos\%C3\%A9\%20Carlos\%20Resmini.html

[11] Correa, H. and Gianesi, I. (2010) Administração Estratégica de Serviços: Operações para a Satisfação do Cliente. Editora Atlas, São Paulo.

[12] Las Casas, A.L. (2005) Marketing: Conceitos, exercícios, casos. 7 Edition, Editora Atlas, São Paulo. 